\title{
Penanggulangan terhadap Anak Berhadapan dengan Hukum dalam Tindak Pidana Penganiayaan
}

\section{Countermeasures against Children Against the Law in Criminal Acts of Persecution}

\author{
Jamillah * \\ Fakultas Hukum Universitas Medan Area, Indonesia
}

\begin{abstract}
Abstrak
Tindak Pidana Penganiayaan yang dilakukan oleh anak yang masih di bawah umur atau anak yang masih dalam lindungan Undang-Undang adalah suatu tindakan yang tidak terpuji, sikap jahat anak itu timbul atau datang dari abad ke abad tidak perna hilang atau lepas dari dari kehidupan anak itu sendiri. Kejahatan anak itu sendiri datang dari pergaulan dalam lingkuan rumah tempat tinggal atau adanya faktor-faktor yang datang dari luar seperti modernisasi. Penanggulangan terhadap anak berhadapan dengan hukum dalam tindak pidana penganiayaan dilakukan sedini mungkin melalui tindakan-tindakan yang bijaksana setelah mengetahui sebabsebab terhadap anak berhadapan dengan hukum dalam tindak pidana penganiayaan yang sebagian besar adalah kaum anak/remaja. Disamping itu perlu diungkapkan sebab-sebab munculnya para pelaku tindak pidana serta beberapa sebab yang ada kaitannya dengan bidang sosial, ekonomi kultural dan mental. Kemudian perlu dipahami akibat-akibat negatif yang membahayakan bagi pelakunya serta dampak yang pasti merugikan dan meresahkan kehidupan masyarakat. Secara global upaya penanggulangan terhadap anak berhadapan dengan hukum dalam tindak pidana penganiayaan dapat dilakukan secara moralistik dan abolionistik.

Kata Kunci: Anak, Hukum, Tindak Pidana Penganiayaan.
\end{abstract}

\begin{abstract}
Criminal Acts of Persecution by a minor or child who is still under the protection of the Act is an act that is not commendable, the child's evil attitude arises or comes from centuries not be lost or apart from the life of the child itself. Child crime itself comes from the association within the home environment or the presence of factors that come from outside such as modernization. Child countermeasures against the law in criminal acts of torture are conducted as early as possible through prudent actions after knowing the causes of children facing the law in the mostly maltreatment of children / adolescents. Besides, it is necessary to disclose the causes of the emergence of the perpetrators of criminal acts and some of the reasons that have to do with the social, cultural and mental economics. Then it is necessary to understand the harmful negative consequences for the perpetrators as well as the definite effects of harming and disturbing the lives of the people. Globally, efforts to overcome the child against the law in the crime of persecution can be done in a moralistic and abolionistic manner.
\end{abstract}

Keywords: Child, Law, Criminal Acts of Persecution.

How to Cite: Jamillah., (2017). Penanggulangan terhadap Anak Berhadapan dengan Hukum dalam Tindak Pidana Penganiayaan. JPPUMA: Jurnal Ilmu Pemerintahan dan Sosial Politik, 5 (1): 60-70

\begin{tabular}{lr}
\hline *Corresponding author: & p-ISSN: 25491660 \\
E-mail: jamilah@staff.uma.ac.id & e-ISSN: 2550-1305
\end{tabular}




\section{PENDAHULUAN}

Anak adalah buah hati setiap keluarga, penerus keturunan, merupakan harta yang tak ternilai bagi orang tuanya. Anak-anak selalu mempunyai sifat ingin tahu, aktif dan penuh harapan. Masa anakanak adalah masa untuk pematangan fisik, kecerdasan, perasaaan (emosional), sosial dan pematangan susila (moral), waktu mereka dilewatkan dalam kegembiraan, perdamaian, dalam permainan, belajar dan tumbuh sehat. Masa depan mereka dibentuk dalam keserasian dan kerja sama, hidup mereka harus memperluas wawasan dan menerima pengalaman baru.

Setiap anak perlu mendapatkan kesempatan yang seluas-luasnya untuk tumbuh dan berkembang dengan wajar baik secara rohani, jasmani maupun sosial. Tetapi dalam kenyataan yang ditemukan ditengah-tengah masyarakat maka perihal tumbuhan kembangnya anak tidaklah semulus apa yang dicanangkan. Ada beberapa kendala yang sangat potensial dalam hal perwujudan untuk mewujudkan tumbuh kembangnya anak secara wajar salah satunya adalah masalah penganiayaan yang terjadi pada anak.

Dalam hal anak melakukan tindak pidana penganiayaan terhadap anak ada dua dimensi dalam lingkup hidup seorang anak, yaitu penganiayaan dalam rumah tangga maupun penganiayaan yang diterima anak diluar rumah tangga. Penganiayaan dalam rumah tangga pada dasarnya berasal dari lingkup keluarga si anak sendiri seperti penganiayaan yang diterima si anak dari orang tuanya atau pihak lainnya yang termasuk dalam golongan keluarga. Sedangkan penganiayaan dalam lingkup di luar rumah tangga adalah penganiayaan yang diterima anak dari lingkungannya, misalnya dari temen sebaya, dari guru atau bahkan dari orang dewasa yang berada di luar golongan keluarga.

Dikaitkan dengan anak yang berhadapan dengan hukum maka dokrin mens rea, actus reus dan voluntary menjadi relevan untuk menentukan pertanggungjawaban pidana anak. Apakah anak memahami tindak pidana yang dilakukan, nyata-nyata melakukan, dan bertindak atas relasi kuasa atas diri anak ketika melakukan tindak pidana. Relasi kuasa dan lingkungan melingkupi diri anak dapat menjadi faktor utama anak melakukan tindak pidana.

Negara Indonesia adalah negara hukum, dimana untuk membuktikan kesalahan seseorang haruslah diselesaikan dengan hukum yang berlaku. Demikian halnya mengenai tindak pidana yang di dalam pembahasan ini dibatasi pada tindak pidana penganiayaan dengan cara kekerasan telah diatur secara tegas dalam Undang-undang No. 11 Tahun 2012 tentang Sistem Peradilan Pidana Anak, bagaimana tata cara penyelesaian pemeriksaan tersebut mulai dari tingkat penyelidikan, penuntutan, dan pemeriksaannya serta putusan pengadilan.

Perkembangan ilmu pengetahuan dan teknologi yang sangat pesat pada saat sekarang membawa pengaruh terhadap pola kehidupan dan pergaulan sosial yang dirasakan oleh manusia semakin canggih dan kompleks, hal ini memerlukan tatanan hukum yang diharapkan dapat berperan penting dalam memberikan petunjukpetunjuk hidup mengenai apa yang boleh dan apa yang tidak boleh dilakukan, dan disertai sanksi bagi yang melanggar tatanan hukum atau norma tersebut. Karena tidak jarang perkembangan dan perubahan yang terjadi memberikan akibat negatif dan juga positif, yakni timbulnya kejahatan serta perbuatanperbuatan yang dapat menjurus kepada ancaman yang membahayakan serta mengakibatkan kerugian bagi masyarakat dan lingkungan sekitar. Hal ini sering disebut oleh berbagai pihak sebagai “ crime is a shadow of civilization".

Secara sosiologi kejahatan merupakan suatu prilaku manusia yang diciptakan oleh masyarakat. Walaupun masyarakat memiliki berbagai macam prilaku yang berbeda-beda, akan tetapi ada di dalamnya bagian-bagian yang tertentu yang memiliki pola yang sama. Keadaan ini dimungkinkan oleh karena 
adanya sistem kaedah dalam masyarakat. Gejala yang dinamakan kejahatan pada dasarnya terjadi dalam proses dimana ada interaksi sosial antara bagian-bagian dalam masyarakat yang mempunyai kewenangan untuk melakukan perumusan tentang kejahatan dengan pihak-pihak mana yang memang melakukan kejahatan.

Hal ini menantang penegak hukum, kalangan ilmuan dan pengamat hukum untuk menggalinya dan menelitinya dan bisa jadi di tempatkan sebagai substansi dari profesinya. Kejahatan merupakan perbuatan atau perilaku seseorang yang melanggar hukum yang telah dilegitimasi berlakunya dalam suatu negara. Ia hadir di tengah masyarakat sebagai model prilaku yang sudah dirumuskan secara yuridis sebagai Pelanggaran dan dilarang oleh hukum dan telah ditetapkan oleh pengadilan yang telah mempunyai kekuatan hukum tetap.

Ketimpangan, keresahan, bencana atau stabilitas sosial merupakan akibatakibat yang ditimbulkan oleh suatu kejahatan.kua;itas akibat destuksi yang ditimbulkan oleh kejahatan itu mempunyai korelasi kuat dengan modusmodus kejahatan yang terjadi dalam berkembang saat ini.

Kerugian yang diderita korban (masyarakat) menjadi bukti bahwa di tengah masyarakat hidup individuindividu yang kurang memiliki pribadi yang menaruh perhatian terhadap kepentingan kemanusiaan, lingkungan dan pembangunan, tidak mampu menyesuaikan diri secara positif serta mau membangun gaya hidupnya dan interaksi sosial secara pathologis.

Berkaitan dengan hal tersebut,maka dalam proses pembangunan nasional, aspek hukum adalah merupakam salah satu aspek dari sekian aspek penunjang/pendukung pembangunan dan turut menentukan peradaban atau perkembangan kehidupan bangsa ini. Hukum dalam fungsinya mengatur seluruh aspek kehidupan berbangsa dan bernegara dapat memberikan konstribusinya secara maksimal dalam pelaksanaan pembangunan nasional. Jika aparat hukum dan seluruh lapisan masyarakat taat dan tunduk dalam norma hukum, maka tidak diragukan lagi rencana pembangunan nasional akan berjalan sesuai dengan apa yang kita harapkan bersama. Tetapi pada kenyataannya tidak semua unsur dalam masyarakat siap dan tunduk kepada aturan yang ada. Oleh karena itu, timbul perbuatan-perbuatan yang melanggar hukum seperti perkelahian dan penganiayaan. (Santoso dan Eva, 2010: 15)

Seperti apa yang dijelaskan oleh Prof.Dr.Achmad Ali, bahwa ;

"Bahwa ternyata seseorang menaati hukum alias tidak melanggar hukum, selain akibat faktor jera atau takut setelah melihat dan menyaksikan atau mempertimbangkan kemungkinan sanksi yang diganjarkan terhadap dirinya jikalau tidak menaati hukum, maka juga bisa saja seseorang menaati hukum, karena adanya tekanan individu lain atau tekanan kelompok. Jika suatu kelompok menentang keras suatu tindakan melanggar hukum, maka akan dapat mencegah seseorang untuk melanggar hukum. Juga mungkin saja, seseorang individu memutuskan untuk menaati suatu aturan hukum karena alasan moral personalnya. Sebaliknya seseorang individu lainnya, dapat memutuskan tidak menaati suatu aturan hukum, juga karena alasan moral".

Merupakan hal yang mutlak bahwa pembentukan watak, karakter serta moral pada individu-individu yang sadar akan dan taat akan aturan hukum maupun yang tidak tunduk terhadap norma hukum yang ada, dan yang telah menjadi aturan dalam kehidupan masyarakat, adalah keadaan lingkungan dan tingkat kesadaran terhadap sesama makhluk sosial sangatlah penting terhadap kelangsungan hidup dan rasa kebersamaan, guna menghindari kejahatan-kejahatan terhadap sesama masyarakat.

Penganiayaan adalah merupakan produk konflik masyarakat yang usianya hampir sama tua dengan umur sejarah 
peradaban manusia di dunia ini. Penganiayaan timbul karena adanya interaksi atau kontak langsung antara individu atau kelompok di dalam masyarakat yang tidak mengindahkan tatanan kehidupan yang ada. Hal itu disebabkan karena setiap anggota masyarakat ingin tetap surveve atau eksis sebagai salah satu makhluk Tuhan yang diberi hak untuk hidup. Bahkan lebih dari manusia dalam kehidupan kesehariannya menuntut untuk berobsesi untuk hidup lebih dari sekedar mempertahankan hidupnya. Obsesi itu misalnya ingin hidup mewah atau mengumpulkan harta sebanyak-banyaknya melebihi dari apa yang menjadi haknya berambisi untuk menduduki jabatan tertentu, atau menjadi pengusaha di dalam masyarakat untuk mewujudkan semua obsesinya itu sering manusia lupa atau sengaja melanggar norma hukumyang ada yaitu dengan melakukan delik penganiayaan.

Didorong oleh keinginan untuk mewujudkan obsesinya serta didukung oleh kondisi lingkungan yang kondusif untuk melakukan delik maka penganiayaan biasa dan berat akhirnya terjadi dan timbul. Maka dari itu dalam KUHP pasal 355 ayat (1) dan (2), menegaskan bahwa :

penganiayaan berat yang dilakukan dengan direncanakan terlebih dahulu, diancam dengan pidana penjara paling lama dua belas tahun,

jika perbuatan itu mengakibatkan kematian maka yang bersalah diancam dengan pidana penjara paling lama lima belas tahun". ${ }^{3}$

Sebagaimana apa yang telah dimuat dalam KUHP khususnya pasal 355 KUHP diatas, bahwa tingkah laku kriminal adalah tingkah laku yang melanggar undang-undang pidana. Bagaimanapun juga tingkatan sifat inmoralnya, kesalahan atau ketidakpatutan suatu perbuatan itu dilarang oleh undang-undang pidana. Sebaliknya, undang-undang pidana secara konvesional merupakan suatu kesatuan peraturan mengenai tingkah laku manusia yang telah diundangkan oleh kekuasaan politik (penguasa) dan berlaku bagi seluruh anggota masyarakat, dengan disertai ancaman hukuman yang dilaksanakan oleh negara. ${ }^{4}$

Pada masa sekarang beragam bentuk kejahatan dan cara melakukan kejahatan itu untuk delik penganiayaan saja, belakangan ini memiliki modus yang semakin banyak dan bervariasi serta berkualitas. Hal ini tentu tidak terlepas dari hasil kontaminasi delik penganiayaan yang terjadi di masyarakat modern yang dapat disaksikan tanpa filter melalui teknologi audio dan visual. Kontribusi teknologi komunukasi dan informasi terhadap kualitas dan kuantitas delik penganiayaan di Indonesia memang tidak bisa dijadikan kambing hitam dalam hal ini, karena hampir setiap negara di dunia ikut merasakannya. Dimana perilaku negatif yang terjadi dibelahan dunia ini secara cepat dan mudah disaksikan oleh anggota masyarakat dunia pada umumnya, dari masyarakat kota hingga ke daerahdaerah terpencil sekalipun dapat menyaksikannya. Begitu pula karena akselerasi perkembangan teknologi dan perubahan kehidupan masyarakat yang tidak diimbangi oleh perkembangan pendidikan moral dan ahklak anggota masyarakat sehingga semakin membuka peluang bagi seseorang atau kelompok untuk melakukan delik penganiayaan.

Implikasi dari kecendrungan meningkatnya delik dalam masyarakat semakin memperbesar akumulasi kekhawatiran, dan rasa aman masyarakat. Mempertahankan dan menyelamatkan jiwa dan harta benda akan menjadi kesibukan tersendiri dalam kehidupan keseharian anggota masyarakat sehingga pada ujung-ujungnya dapat menghilangkan konsentrasi dan perhatian masyarakat untuk ikut berpatisipasi secara maksimal dan proses pembangunan bangsa dan negara.

Perkembangan hukum di Indonesia sangat mengakomodir kepentingan pelaksana perlindungan anak dari aspek kekerasan seperti : 
- Undang-undang No. 4 Tahun 1997 tentang kesejahteraan anak

- Undang-undang No. 12 Tahun 1995 tentang pemasyarakatan

- Undang-undang No. 3 Tahun 1997 tentang pengadilan anak

- Undang-undang No. 23 Tahun 2002 tentang perlindungan anak

- Undang-undang No. 13 Tahun 2003 tentang ketenagakerjaan

- Undang-undang No. 11 Tahun 2012 tentang sistem peradilan pidana anak

Tetapi dalam kenyataannya apabila diperhatikan dari berita-berita di beberapa media baik itu televisi maupun media masa yang bersifat harian terlihat beritaberita penganiayaan yang menimpa anak sepertinnya sangat tidak berkesudahan, padahal Indonesia memiliki perundangundangan yang beranekaragam dalam mengantisipasi dan memberikan perlindungan terhadap anak. Seperti anak yang disakiti oleh kedua orang tuanya, anak yang dilecehkan secara seksualnya, dan lain bentuk-bentuk penganiayaan. Belum lagi masalah pekerja anak yang sangat potensial menimbulkan penganiayaan bagi anak. Keadaan-keadaan ini tentunya memberikan tanda tanya jawab yang besar bagi perlindungan anak di Indonesia terutama sebagai objek penganiayaan.

Dalam upaya menempatkan posisi anak ke dalam subjek hukum yang normal atau layaknya seseorang yang disebut sebagai subjek hukum, ada beberapa faktor yang menjadi pertimbangan utama meliputi unsur-unsur internal maupun unsur-unsur eksternal,yaitu :

1) Unsur internal dalam diri anak

Subjek hukum,sebagai seorang anak juga digolongkan sebagai human right yang terkait dalam ketentuan-ketentuan peraturan perundang-undangan. Ketentuan dimaksud diletakkan pada anak dengan golongan orang yang belum dewasa, seorang yang berada dalam perwalian, orang yang tidak mampu melakukan perbuatan hukum.

Persamaan hak dan kewajiban anak (recht gelijkstelling en kind plicht), seorang anak juga mempunyai hak dan kewajiban yang sama dengan orang dewasa yang diberikan oleh ketentuan perundangundangan dalam melakukan perbuatan hukum. Hukum memposisikan anak sebagai mediator hukum untuk dapat memperoleh hak-hak dan atau melakukan kewajiban-kewajiban dan atau dapat disejajarkan dengan kedudukan orang dewasa atau disebut sebagai subjek hukum normal.

2) Unsur eksternal pada diri anak :

Ketentuan hukum atau persamaan kedudukam dalam hukum (gelijkstelling in voor het rech), dapat memberikan legalitas formal terhadap anak sebagai seorang yang tidak mampu untuk berbuat peristiwa hukum yang dicantumkan oleh ketentuan-ketentuan peraturan hukum itu sendiri. Demikian pula ketentuanketentuan yang membuat perincian tentang klarifikasi kemampuan dan kewenangan berbuat peristiwa hukum dari anak yang bersangkutan.

Hak-hak istimewa (bijzondere rechten) yang diberikan negara untuk pemerintah yang bersilsilah dari Undangundang Dasar 1945 dan perundangundangan lainnya.

Hukum dalam fungsinya mengatur seluruh aspek kehidupan berbangsa dan bernegaraa dapat memberikan konstribusinya secara maksimal dan pelaksanaan pembangunan nasional. Jika aparat hukum dan seluruh lapisan masyarakat taat dan tunduk terhadap norma hukum, maka tidak diragukan lagi rencana pembangunan nasional akan berjalan sesuai dengan apa yang kita harapkan bersama. Tetapi pada kenyataannya tidak semua unsur dalam masyarakat siap dan tunduk kepada aturan yang ada. Oleh karena itu, timbul perbuatan-perbuatan yang melanggar hukum seperti perkelahian dan penganiayaan.

Implikasi dari kecenderungan meningkatnya delik dalam masyarakat semakin memperbesar akumulasi kecemasan, kekhawatiran, dan rasa aman masyarakat. Mempertahankan dan 
menyelamatkan jiwa dan harta benda akan menjadi kesibukan tersendiri dalam kehidupan keseharian anggota masyarakat sehingga pada ujung-ujungnya dapat menghilangkan konsentrasi dan perhatian masyarakat untuk ikut berpatisipasi secara maksimal dalam proses pembangunan bangsa dan negara.

\section{PEMBAHASAN}

Perlindungan anak adalah segala usaha yang dilakukan untuk menciptakan kondisi setiap anak agar dapat melaksanakan hak dan kewajibannya demi perkembangan dan pertumbuhan anak secara wajar baik fisik, mental dan sosial (Gultom, 2008: 33) Perlindungan anak merupakan perwujudan adanya keadilan dalam suatu masyarakat, dengan demikian perlindungan anak diusahakan dalam berbagai bidang kehidupan bernegara dan bermasyarakat. Hukum merupakan jaminan bagi perlindungan anak. Aris Gosita mengemukakan bahwa kepastian hukum perlu diusahakan demi kelangsungan kegiatan perlindungan anak dan mencegah penyelewengan yang membawa akibat negatif yang tidak diinginkan dalam pelaksanaan perlindungan anak. (Gosita, 1939: 19)

Selanjutnya perlindungan hukum bagi anak dapat diartikan sebagai upaya hukum terhadap berbagai kebebasan dan hak asasi anak (Fundamental rights and freedom of children) serta berbagai kepentingan yang berhubungan dengan kesejahteraan anak. Tetapi dalam hal ini perlindungan hukum dalam proses peradilan, melainkan mencakup segala hal atas kebebasan si anak untuk memperoleh perlakuan yang layak seperti warga Negara lainnya. Makin meningkatkan suasana kekerasan dan ketidaktentraman dalam lingkungan kehidupan sehari-hari di dalam suatu kota/wilayah akan menempatkan anak-anak dalam risiko yang sangat gawat. Di mana dia tidak lagi merasa aman bermain bersama anak-anak lainnya. Karena secara tidak langsung mengakibatkan kemerdekaan si anak menjadi terampas.
Dengan demikian hal tersebut di atas, dewasa ini mengakibatkan banyaknya anak yang melakukan kejahatan yang merisaukan masyarakat terlebih lagi apabila si anak sampai melakukan pelanggaran terhadap hukum pidana. Dalam hal ini perlu kita ketahui bahwa sistem pertanggungjawaban pidana anak (termasuk pemberian tindakan) pada dasarnya masih sama dengan sistem pertanggungjawaban orang dewasa yaitu berorientasi pada si pelaku secara pribadi/individual. Penerapan prinsip ini kepada anak perlu dikaji, karena anak belum dapat dikatakan sebagai individu yang mandiri secara penuh. Oleh karena itu penerapan prinsip umum ini harus dilakukan hati-hati dan selektif, dengan mengingat tingkat kematangan/kedewasaan setiap anak adalah berbeda. Tentu masalah anak lebih merupakan masalah struktural. Terlebih karena sifat kekurangmandirian dan ketergantungan si anak, maka anak yang melakukan kenakalan atau kejahatan sebenarnya adalah "korban lingkungan", oleh karena itu sepantasnya dikembangkan pemikiran/gagasan/strategi pertanggungjawaban struktural/fungsional artinya pemidanaan tidak hanya berfungsi untuk mempertanggungjawabkan dan membina si anak sebagai pelaku kejahatan. Melainkan hal ini juga berfungsi untuk mempertanggungjawabkan dan membina (melakukan treatment) si anak sebagai pelaku kejahatan, tetapi juga berfungsi untuk mempertanggungjawabkan dan membina/mencega pihak-pihak lain yang struktural/fungsional mempunyai potensi dan kontribusi besar untuk terjadinya kejahatan/tindak pidana yang dilakukan si anak.

Terkait upaya memberikan perlindungan terhadap anak yang berhadapan dengan hukum, sistem peradilan pidana anak harus dimaknai secara luas, ia tidak hanya dimaknai hanya sekedar penanganan anak yang berhadapan dengan hukum semata. Namun sistem peradilan pidana anak 
harus juga dimaknai mencakup akar permasalahan (root causes) mengapa anak melakukan perbuatan pidana dan upaya pencegahannya. Lebih jauh, ruang lingkup sistem peradilan pidana anak mencakup banyak ragam dan kompleksitas isu mulai dari anak melakukan kontak pertama dengan polisi, proses peradilan, kondisi tahanan, dan reintegrasi sosial, termasuk pelaku-pelaku dalam proses tersebut. Dengan demikian, istilah sistem peradilan pidana anak merujuk pada legislasi, norma dan standar, prosedur, mekanisme dan ketentuan, institusi dan badan yang secara khusus diterapkan terhadap anak yang melakukan tindak pidana.

Mengacu pada proses ini, maka terdapat 3 (tiga) tahap peradilan anak, tahap pertama, mencakup pencegahan anak dari tindak pidana. Tahap ini meliputi implementasi tujuan kebijakan sosial yang memungkinkan anak dalam penumbuhannya sesuai dengan kepentingan terbaiknya. Tahap kedua, ditandai anak bersentuhan dengan prosedur formal sistem peradilan pidana. Tahap ini merupakan bentuk tanggung jawab anak melalui proses peradilan pidana. Tahap ketiga resosialisasi diawali dari proses isolasi di lembaga pemasyarakatan sampai pembebasan anak.

Sebagaimana dengan kerangka diatas, standar internasional sistem peradilan pidana anak pada prinsipnya ditujukan untuk mendorong kekhususan praktik-praktik peradilan pidana anak dan mengembangkan sistem peradilan pidana yang berbeda sehingga perlakuan terhadap anak yang berhadapan dengan hukum sesuai dengan usia dan tingkat kematangannya. Hal ini dikarenakan terdapatnya kesenjangan tingkat kematangan antara orang dewasa dan anak, baik secara moral, kognitif, psikologis dan emosional. Oleh karenannya dalam membangun sistem peradilan anak semestinya berperspektif bahwa anak yang berhadapan dengan hukum pada dasarnya merupakan korban, meskipun anak tersebut telah melakukan tindak pidana.
Secara prinsip penangulangan terhadap anak berhadapan dengam hukum dalam tindak pidana penganiayaan akan lebih baik dan efektif jika dilakukan sejak dini (upaya preventif) secara simultan dan holistik yaitu sinergi peran keluarga/orang tua, masyarakat termasuk pemuda, aparat kepolisian dan individu yang bersangkutan.

Upaya teknis yang dapat dilakukan berdasarkan aspek demand antara lain sebagai berikut (Anwari, tt: 19): 1) Pendeteksian terhadap anak: Perhatikan perubahan pada diri si anak (bohong, bolos, bengong, bego dan bodoh); Perhatikan prestasi, aspirasi dan masalah yang ada di sekolah, 2) Perhatikan kegiatan keagamaan si anak dan harga diri si anak, 3) Perhatikan perubahan emosi dan hubungan anak dan orang tua, 4) Pendekatan psikologis, 5) Faktor individu, 6) Ciptakan hubungan hangat dalam keluarga, 7) Ciptakan kesadaran bahwa keberhasilan dan kegagalan merupakan usaha sendiri, orang lain hanya fasilitator, 8) Libatkan secara intensif si anak terhadap aktifitas keagamaan, 9) Faktor keluarga: Ciptakan keharmonisan dalam keluarga, hilangkan jarak antara orang tua dengan membangun suasana demokratis, Ciptakan komunikasi yang produktif dan terapkan aturanyang jelas.

Faktor Teman Sebaya, Sekolah dan Lingkungan: Perhatikan prestasi belajar anak dan terus memberi semangat, Cermati latar belakang dan prilaku teman-teman terdekat si anak, Cermati jika ada perubahan kebiasaan si anak dari biasanya. Lakukan pengawasan terhadap alat-alat sekolah, jikalau ada hal yang aneh.

Penanggulangan terhadap anak berhadapan dengan hukum dalam tindak pidana penganiayaan dilakukan sedini mungkin melalui tindakan-tindakan yang 
bijaksana setelah mengetahui sebab-sebab terhadap anak berhadapan dengan hukum dalam tindak pidana penganiayaan yang sebagian besar adalah kaum anak/remaja. Disamping itu perlu diungkapkan sebabsebab munculnya para pelaku tindak pidana serta beberapa sebab yang ada kaitannya dengan bidang sosial, ekonomi kultural dan mental. Kemudian perlu dipahami akibat-akibat negatif yang membahayakan bagi pelakunya serta dampak yang pasti merugikan dan meresahkan kehidupan masyarakat. Secara global upaya penanggulangan terhadap anak berhadapan dengan hukum dalam tindak pidana penganiayaan dapat dilakukan secara moralistik dan abolionistik. Cara moralistik dalam upaya menanggulangi terhadap anak berhadapan berhadapan dengan hukum dalam tindak pidana penganiayaan adalah menitikberatkan kepada pembinaan moral dan membina kekukuhan mental masyarakat, juga membina moral dan mental anak remaja (Anwari, tt: 23). Dengan pembinaan moral baik masyarakat lebihlebih anak remaja tidak mudah terjerumus dalam tindak pidana penganiayaan. Nilainilai moral akan mampu menggagalkan setiap orang bermoral dengan sendirinya akan menjauhkan diri dari tindak pidana penganiayaan. Dengan pembinaan agama sebaik-baiknya berarti masyarakat termasuk anak remaja akan memiliki kekuatan mental yang kokoh sehingga tidak mudah melanggar hukum baik tertulis maupun tidak tertulis, yang berarti pula tidak akan melakukan tindak pidana penganiayaan.

Cara abolisionistik dalam usaha menanggulangi terhadap anak berhadapan dengan hukum dalam tindak pidana penganiayaan adalah mengurangi, bahkan untuk menghilangkan sebab-sebab yang mendorong para pelaku dalam tindak pidana penganiayaan di wilayah Indonesia dengan motivasi apapun, menutup kesempatan untuk menggunakan sarana pelayanan umum baik milik pemerintah maupun swasta di dalam menunjang lancarnya kejahatan yang dilakukan anak secara melawan hukum, memelihara kewaspadaan masyarakat terhadap anak berhadapan dengan hukum dalam tindak pidana penganiayaan. Dewasa ini yang tidak kalah pentingnya ialah meningkatkan usaha untuk memperkecil, bahkan meniadakan faktor-faktor yang membuat para remaja terjerumus dalam tindak pidana penganiayaan. Faktor-faktor tersebut antara lain, broken home, frustrasi, pengangguran dan kurangnya sarana hiburan bagi anak/remaja.

Usaha penanggulangan terhadap anak berhadapan dengan hukum dan tindak pidana penganiayaan, khususnya bagi kaum/remaja tersebut di atas sesuai dengan upaya penanggulangan kejahatan pada umumnya. Asas umum dalam penanggulangan kejahatan (crime prevention) yang banyak dipakai oleh Negara-negara yang telah maju, asas ini merupakan gabungan dari 2 sistem yakni :

Cara moralistic, dilaksanakan dengan menyebarluaskan ajaran-ajaran agama, moral, perundang-undangan yang baik dan sarana-sarana lain yang dapat mengekang nafsu untuk berbuat kejahatan.

Cara abolisionistik, berusaha memberantas, menanggulangi kejahatan dengan memberantas sebabmusababnya umpamanya kita ketahui bahwa faktor tekanan ekonomi (kemelaratan) merupakan salah satu faktor penyebah kejahatan maka usaha untuk mencapai kesejahteraan untuk mengurangi kejahatan disebabkan oleh faktor ekonomi merupakan cara abolisionistik.

Menanggulangi terhadap anak berhadapan dengan hukum dalam tindak pidana penganiayaan tidak jauh berbeda dengan upaya penanggulangan kejahatan pada umumnya. Cara moralistik dan abolisionistik dapat secara bersama-sama akan tetapi dapat pula digunakan salah satu dari keduanya. Penggunaan dengan cara-cara yang ada hendaknya memperhatikan kondisi yang paling 
memadai untuk mencapai hasil yang diharapkan. Menanggulangi sedini mungkin untuk memperoleh tingkat usaha efisien dan efektif, upaya ini berarti pula sebagai pencegahan terhadap timbulnya anak berhadapan dengan hukum dalam tindak pidana penganiayaan oleh masyarakat luas termasuk usia dewasa dan orangtua.

Selain itu juga untuk penanggulangan terhadap masalah anak berhadapan dengan hukum dalam tindak pidana penganiayaan yang sangat membahayakan generasi muda dan juga masa depan bangsa Indonesia didasarkan pada cara-cara sebagai berikut :

1) Penyuluhan dan prevensi

Tujuan dari pada penyuluhan adalah memberikan motivasi serta pengarahan pada masyarakat terutama kaum remaja atau generasi penerus/muda baik mengenai anak berhadapan dengan hukum dalam tindak pidana penganiayaan demikian juga mengenai perundangundangannya sehingga masyarakat memahami dan menyadarinya. Tujuan dari prevensi adalah mencegah atau melindungi masyarakat luas khususnya generasi muda dan remaja dari tindak pidana penganiayaan serta menyadarkan mereka tentang bahaya yang ditimbulkan dari tindak pidana penganiayaan tersebut.

2) Pemulihan dan rehabilitasi

Tujuan dari pemulihan dan rehabilitasi adalah bagaimana caranya mengobati atau memulihkan anaknberhadapan dengan hukum dalam tindak pidana penganiayaan dan merehabilitasinya sedemikian rupa sehingga dapat kembali lagi kemasyarakat sebagai warga negara masyarakat yang baik.

\section{3) Penegak hukum}

Tujuan dari penegakan hukum adalah melenyapkan tindak pidana penganiayaan terhadap anak berhadapan dengan hukum dalam tindak pidana penganiayaan yang terhadap anak berhadapan dengan hukum dalam tindak pidana penganiayaan dilakukan anak. Dalam penegakan hukum ini tidak terlepas dari pada apa yang biasa disebut dengan instansi terkait dalam hal ini adalah aparat penegak hukum yang dapat dibagi menjadi 2 (dua) kategori yakni pertama manusianya dan perangkat peraturan perundangan yang ada. Sebagaimana diketahui bahwa aparat penegak hukum itu adalah Polisi Republik Indonesia (Polri), Jaksa dan Hakim yang dikenal dengan istilah MAKEHJAPOL (Mahkama Agung, Kehakiman, Kejaksaan Agung, Kepolisian) serta penasehat hukum yang berperan memberikan bantuan hukum. Di daerah-daerah untuk pemecahan masalah dalam tindak pidana pada umumnya pidana penganiayaan pada khususnya diadakan rapat kerja antar penegak hukum yang dikenal dengan RAKERGAKKUM dan adapun peserta rapat dimaksud adalah kejaksaan, Kehakiman (Pengadilan Negeri/Hakim, Lembaga Pemasyarakatan (LP) dan Kepolisian. Berbagai kegiatan telah dilakukan di bidang ini oleh instansi yang terkait maupun yang dikoordinasikan oleh bidang tindak pidana penganiayaan; kegiatan-kegiatan tersebut adalah sebagai berikut (Anwari, tt: 27): Mengadakan peninjauan secara terhadap perundang-undangan yang menyangkut penganiayaan apakah masih ada atau tidak lagi, dan Mengusahakan ségera diundangkannya suatu undang-undang mengenai penganiayaan.

$$
\text { Peranan Bakolak sebagai Badan }
$$

Koordinasi adalah menggerakkan/menstimulir agar instansi-instansi yang terkoordinir di dalamnya sesuai dengan bidang masing-masing.

Untuk mengawasi agar tidak terjadi kebocoran dari sumber-sumber resmi serta mencegah penggunaanpenggunaan yang tidak wajar yang tidak dapat menjurus terhadap anak dengan hukum dalam pidana penganiayaan pada umumnya dikenal 3 (tiga) macam pendekatan: 1) 
Pendekatan kebudayaan, dengan asumsi bahwa kegiatan penerangan yang berhasil harus bersifat persuasif edukatif dan manusiawi dengan menyadari sepenuhnya bahwa kebudayaan yang merupakan sumber utama dari segenap kekuaaan yang diperlihatkan bagi pembinaan bangsa dengan memperhatikan tata nilai yang hidup dan berkembang di masyarakat. 2) Pedekatan faktual, dengan asumsi bahwa pengetahuan yang tepat dan seimbang tentang efek-efek dari tindak pidana penganiayaan. 3) Pendekatan menakut-nakuti (secara approach) dengan asumsi bahwa dengan ketakutan tentang tindak pidana penganiayaan tersebut dapat mencegah, menghentikan terhadap anak berhadapan dengan hokum tindak penganiayaan.

Demikian juga pemerintah baik melalui program Jaksa Masuk Desa maupun melalui Departemen Kehakiman melaksanakan penyuluhan hukum ke desa-desa di séluruh Indonesia yang di dalam materinya disampaikan mengenai masalah-masalah undang-undang pidana penganiayaan serta akibat yang ditimbulkannya.

\section{SIMPULAN}

Penangulangan terhadap anak berhadapan dengam hukum dalam tindak pidana penganiayaan akan lebih baik dan efektif jika dilakukan sejak dini (upaya preventif) secara simultan dan holistik yaitu sinergi peran keluarga/orang tua, masyarakat termasuk pemuda, aparat kepolisian dan individu yang bersangkutan. Usaha penanggulangan terhadap anak berhadapan dengan hukum dan tindak pidana penganiayaan, khususnya bagi kaum/remaja tersebut di atas sesuai dengan upaya penanggulangan kejahatan pada umumnya. Asas umum dalam penanggulangan kejahatan (crime prevention) yang banyak dipakai oleh Negara-negara yang telah maju yakni moralistic dan abolisionistic. Cara moralistik dalam upaya menanggulangi terhadap anak berhadapan berhadapan dengan hukum dalam tindak pidana penganiayaan adalah menitikberatkan kepada pembinaan moral dan membina kekukuhan mental masyarakat, juga membina moral dan mental anak remaja. Cara abolisionistik dalam usaha menanggulangi terhadap anak berhadapan dengan hukum dalam tindak pidana penganiayaan adalah mengurangi, bahkan untuk menghilangkan sebab-sebab yang mendorong para pelaku dalam tindak pidana penganiayaan di wilayah Indonesia dengan motivasi apapun, menutup kesempatan untuk menggunakan sarana pelayanan umum baik milik pemerintah maupun swasta di dalam menunjang lancarnya kejahatan yang dilakukan anak secara melawan hukum, memelihara kewaspadaan masyarakat terhadap anak berhadapan dengan hukum dalam tindak pidana penganiayaan.

Cara moralistik dan abolisionistik dapat secara bersama-sama akan tetapi dapat pula digunakan salah satu dari keduanya. Penggunaan dengan cara-cara yang ada hendaknya memperhatikan kondisi yang paling memadai untuk mencapai hasil yang diharapkan. Menanggulangi sedini mungkin untuk memperoleh tingkat usaha efisien dan efektif, upaya ini berarti pula sebagai pencegahan terhadap timbulnya anak berhadapan dengan hukum dalam tindak pidana penganiayaan oleh masyarakat luas termasuk usia dewasa dan orangtua.Selain itu dapat juga dilakukan dengan cara penyuluha dan prevensi; pemulihan dan rehabilitasi; serta penegakan hukum

\section{DAFTAR PUSTAKA}

\section{A. Buku}

A.Mashur Efendi, Dimensi/Dinamika Hak Asasi Manusia dalam Hukum Nasional dan Internasional, Ghalia Indonesia, Jakarta, 1994.

Achmad Ali, Menguak Teori Hukum dan Teori Peradilan. Kencana. Jakarta, 2009 
Adam Graycar, The Ageof Criminal Responsibility, Australian Institute ofCriminology, 2000

Alicia Victor, Sub-Report on Delivery: Restorative Justice,The National Prosecuting Authority of South Africa, 2006

Andre Ata Ujan, Filsafat Hukum: Membangun Hukum, Membela Keadilan, Penerbit Kanisius, Yogyakarta, 2009

Ann Skelton \& Boyane Tshehla, Child Justice in South Africa, Institute for Security Studies, Monograph 150 September 2008.

Arif Gosita, Masalah Perlindungan Anak, Akademi Pressindo, Jakarta, 1989

Bambang Waluyo, Viktimologi Perlindungan Korban dan Saksi, Sinar Grafika.Jakarta, 2011

BardaNawawi Arief, Beberapa aspek KebijakanPenegakan dan Pengembangan Hukum pidana, PT; Ciba Aditya Bakti, Bandung, 1998

Hangama Anwari. Justice for the Children: the situation for children in conflictwiththe law in Afghanistan, UNICEF and AIHRC, tanpa tahun, hal. 19

Kartini Kartono, Patologi Sosial, Raja Grafindo Persada, Jakarta, 2003

Leden Marpaung, Tindak Pidana Terhadap Nyawa dan Tubuh, Sinar Grafika,Jakarta,20oo.

Lilik Mulyadi, 2003. Kapita Selekta Hukum Pidana Kriminologi dan Viktimologi.

Djambatan,Denpasar,2003

Maidin Gultom, Perlindungan Hukum Terhadap Anak Dalam SistemPeradilanPidana Anak Di Indonesia, Rafika Aditama, Bandung, 2008.

Maulana Hasan Wadong, Advokasi Dan Hukum Perlindungan Anak, PT.Grasindo, Jakarta, 2000

Moh. Mahfud MD, Dasar Struktur Ketatanegaraan Indonesia, Rieneka Cipta,Jakarta, 1993.

Ninik Widiayanti-Panji Anoraga. Perkembangan Kejahatan Dan Masalahnya (ditinjau dari segi kriminologi dan sosial). Pradnya Paramita. Jakarta. 1987.

Rena Yulia, Viktimologi Perlindungan Hukum terhadap Korban Kejahatan. Graha Ilmu, Yogyakarta, 2010
Romli Atmasasmita, Capita Selecta Kriminologi, Armico, Bandung, 2004

Sahepaty, Bunga Rampai Viktimologi. Eresco, Bandung, 1995

Salahudin. KUHP Kitab Undang-undang Hukum Pidana dan KUHAP Kitab Undang-Undang Acara Pidana, Visamedia Jakarta 2009.

Satochid Kartanegara, Kumpulan Kuliah Bagian I, Balai Lektur Mahasiswa, Jakarta, 1982.

Soedjono, Konsepsi Kriminologi, Alumni, Bandung, 2004

Soerjono Soekanto \& Sri Mamudji, Penelitian Hukum Normatif (Suatu Tinjauan Singkat), Rajawali Pers, Jakarta, 2001, hal. 13-14.

Tambah Sembiring, Pemeriksaan Pendahuluan Dalam KUHAP, FH-USU, Medan,1983.

Ter Haar, Azas-Azas Hukum Adat, Armico, Bandung, 1984

Topo santoso dan Eva Achjani Zulf. Kriminolgi. Raja Grafindo Persada Jakarta. 2010

\section{B. Perundang-Undangan}

Kitab Undang-Undang Hukum Pidana

Undang-Undang Hukum Perdata

Undang-Undang No.4 Tahun1979tentangKesejahteraan Anak

Undang-Undang No. 12 Tahun1995 tentang Pemasyarakatan

Undang-Undang No. 3Tahun1997tentangPengadilanAnak.

Undang-Undang No. 23 TahunzooztentangPerlindunganAnak

Undang-Undang No. 13 Tahun 2003 tentang Ketenagakerjaan.

Undang-Undang No. 11 Tahun 2012 tentang Sistem PeradilanPidana Anak

\section{Majalah/Intenet}

Inter-ParliamentaryUnion \& UNICEF, Improving the Protection of ChildreninConflict with the Law in South Asia: A regional parliamentary guide onjuvenilejustice, UNICEF ROSA, 2006

UNICEF, Child Protection Information Sheet, Child Protection INFORMATION

Sheet, 2006

www.africanchildforum.org/Documents/ageofr esponse.pdf 